\title{
A Managerial Decision Tool for R\&D Outsourcing and Partner Selection in High-Technology Industries
}

\author{
Iivari Kunttu
}

\author{
"Our own $R \& D$ relies quite heavily on long-term relationships") \\ with competent $R \& D$ suppliers. However, we have noticed \\ that we tend to continue our outsourcing activities without \\ regular reconsideration even if it would perhaps be more \\ feasible to carry out some outsourced tasks internally. In a \\ similar manner, performing some tasks that we have always \\ done internally might be more efficient if we outsourced \\ them. Therefore, we have realized it is important to consider \\ our R\&D outsourcing and insourcing practices based on \\ rational reasoning.
}

R\&D Manager (Interviewee in this study)

\begin{abstract}
Deciding which tasks and projects are best performed in-house and which should be outsourced to external suppliers are, alongside the supplier selection process, among the key challenges for $R \& D$ managers operating in high-technology firms. This study presents a decision tool for evaluating whether to pursue $R \& D$ tasks in-house or to outsource them. The tool also helps R\&D managers to evaluate which of the supplier candidates would be best suited to undertake the task to be outsourced. The tool is based on four views of evaluation that have both managerial and theoretical roots: identity, dependence, efficiency, and competence. The tool has been developed in a qualitative multiple case study based on $R \& D$ supplier relationships and has been empirically tested in an R\&D organization.
\end{abstract}

\section{Introduction}

High-technology firms now recognize that strategic investments in collaborations with external $R \& D$ partners are critical to developing successful product innovations. However, the challenges of this approach require companies to enhance and reorganize their R\&D capabilities to access competencies and resources from external R\&D suppliers through outsourcing (Geringer, 1991). Accordingly, suppliers of $R \& D$ functionality have an increasingly important role in product development and innovation (Johnsen, 2009; Quinn, 2000; Wagner \& Hoegl, 2006). For this reason, it is essential for companies to understand which kinds of external partners are best suited to $R \& D$ alliances (Paananen, 2012) and how the tasks and projects suitable for outsourcing should be selected (Geringer, 1991). Similarly, it is important for the effective imple- mentation of R\&D in the dynamic environment of hightechnology industries that managers understand which resources are necessary in their organization and which resources can be outsourced to complement internal resources, improve $R \& D$ performance, or to split costs and risk (Eisenhardt \& Schoonhoven, 1996; Verona, 1999).

$R \& D$ managers must regularly decide how best to utilize an external supplier's resources and simultaneously deploy and develop their firm's own internal R\&D resources. To serve this end, there are several approaches to facilitate the decision making concerning outsourcing decisions. Literature on organizational boundaries (Santos \& Eisenhardt, 2005) presents four conceptions - efficiency, competence, dependence, and organizational identity - all of which have a solid theoretical background and are applied in industry. 


\section{A Managerial Decision Tool for R\&D Outsourcing and Partner Selection}

\section{Iivari Kunttu}

The efficiency conception considers the governance costs that the collaboration with external suppliers creates for the customer organization. According to this conception, an activity should be outsourced if the external supplier's production costs and the relationship governance costs together are less than the customer's internal production costs (Dyer, 1996; Rindfleisch \& Heide, 1997). This kind of decision making has been a popular choice, especially in those industries characterized by intense price competition and a stable structure (Santos \& Eisenhardt, 2005). However, in the dynamic environments of high-technology industries, market requirements, competition, and speed of technology renewal (Heide \& Weiss, 1995) create a constant need for developing and sustaining product innovation capabilities, and therefore, capabilities provided by external partnerships steer the outsourcing decision more than the direct and indirect costs of the partnerships.

The competence conception emphasizes the value of knowledge resources, special competences (Lambe et al., 2002; Wittmann et al., 2009), and dynamic capabilities (Teece et al., 1997) provided by external R\&D suppliers. Therefore, under this conception, outsourcing and partner selection decisions are based on valuable and unique competences provided by suppliers. However, when making decisions concerning outsourcing, managers also have to consider how dependent the customer will become on the supplier's specialist competences and capabilities that may be difficult to substitute or imitate (Gulati \& Sytch, 2007).

According to the dependence conception, the risk of high dependence on external partners in strategically important technology areas may make the customer vulnerable to a supplier's opportunistic behaviour: a vulnerability that may cause the customer to favour performing those activities in-house (Mayer \& Nickerson, 2005). Therefore, power-based decisions aim to control the dependence on external supplier partners by retaining crucial projects in-house and outsourcing activities that will not cause dependence on single suppliers.

The fourth conception, organizational identity (Weick et al., 2005), is based on managerial experience, personal views and attitudes, as well as organizational traditions (Santos \& Eisenhardt, 2005). Identity-based decisions are usually based on prior experience of supplier collaboration, and therefore, identity-based outsourcing decisions often favour continuation of outsourcing practices with trusted, familiar suppliers. Thus, identitybased decision making often lacks a systematic process to support rational reasoning (Bäck \& Kohtamäki, 2015).
A recent study on $R \& D$ outsourcing decision making (Bäck \& Kohtamäki, 2015) reveals a central problem: R\&D managers may either make decisions based on experience- and identity-based reasoning, or alternatively, they may focus solely on one rational viewpoint such as governance cost or supplier competences. Therefore, Bäck and Kohtamäki (2015) suggest that managers should consider a wider range of factors, including the dependence, efficiency, and competence viewpoints, to facilitate rational and systematic decision making when evaluating outsourcing and insourcing activities. Accordingly, the present study presents a practical decision-making tool based on the four abovementioned conceptions of R\&D measurement to support outsourcing decisions. The tool is designed primarily for two purposes: i) to help managers decide whether or not a particular piece of development work (task) is suitable to be outsourced to an external technology partner (supplier) and ii) to help them decide which of the known supplier candidates is best suited to perform the task. Therefore, the tool is primarily designed to support decisions concerning supplier involvement in the $R \& D$ function, not research or innovation collaboration that usually emphasizes joint knowledge creation and learning with research partners (Bäck \& Kohtamäki, 2016; Laursen \& Salter, 2006).

\section{Background}

\section{From organizational identity to strategy-based decision making}

As described in the introduction, the view of organizational identity is based on the observation that managerial cognition and managers' personal experiences, views, and attitudes, alongside an organization's traditions, tend to dominate other rationally grounded reasons when technology firms make decisions on R\&D outsourcing or insourcing. The combination tends to promote those decisions that are aligned with the current, tradition-based identity (Brown \& Starkey, 2000; Santos \& Eisenhardt, 2005). Therefore, when a firm has a strong organizational identity, it can dominate to the extent that the firm will only act in a way consistent with its existing identity, and it can mean that its decision making is not always entirely rational (Brown \& Starkey, 2000; Santos \& Eisenhardt, 2005). Accordingly, identity often affects decisions on R\&D outsourcing because any decision that might challenge the traditional way of working is not easily accepted in an organization, even if there is clear evidence of improved performance, efficiency, or better technological capabilities, for example (Santos \& Eisenhardt, 2005). One way to overcome this limitation would be to en- 


\section{A Managerial Decision Tool for R\&D Outsourcing and Partner Selection}

\section{Iivari Kunttu}

courage a clear R\&D strategy that could steer identitybased decisions by defining the core competence areas and core business in which the internal $R \& D$ function wants to be involved (Bäck \& Kohtamäki, 2015). Thus, an organization should devote effort to determining the valuable competence areas it wants to own and develop, and also to deciding upon the areas that can be outsourced. Doing so would permit such an organization to define its identity through a consensual strategy that facilitates systematic and rational decision making.

\section{Dependence on suppliers}

In networked, knowledge-intensive technologies, firms may be dependent on the special competences, resources, and skills provided by their suppliers. This is because these resources are typically difficult to substitute or imitate (Gulati \& Sytch, 2007) and, consequently, it is expensive and difficult to switch partners (Heide \& Weiss, 1995). Accordingly, firms must decide how much dependence on external suppliers they can tolerate to improve their R\&D performance (Gulati \& Sytch, 2007), or alternatively, they must ensure that their strategically crucial $R \& D$ projects are carried out in-house to avoid dependence. Internalizing these projects may, in turn, limit the customer firms' access to the unique competences and skills possessed by their partners (Mayer \& Nickerson, 2005). Therefore, when making decisions on outsourcing an $R \& D$ project or task, $R \& D$ managers must usually consider the extent to which outsourcing would make the customer firm dependent on the supplier. The key factors would relate to the time and cost of switching a partner or bringing the task in-house. The cost of switching partners can be significant if the partnership requires investment or competence development by both parties. In addition, subsequent partner switching would be complicated if the competences of the supplier are very rare and difficult to imitate. For this reason, companies may decide to maintain internal competences in their critical technology areas even as they employ suppliers on tasks in those areas, or they may decide to employ several sources in each technology area. Previous research has shown that customers tend to tolerate dependence on those suppliers with whom they have a long-term and close relationship (Bäck \& Kohtamäki, 2015). This is because previous positive experience and familiarity with a supplier serves to increase mutual trust, which in turn tends to increase the tolerance of dependence.

\section{Governance efficiency}

When product development projects are outsourced to external partners, the customer firm must take care of the governance of the project and also the relationship with the supplier. $R \& D$ project governance costs are transaction costs that arise from the mechanisms related to agreements, project management, information sharing, as well as negotiation, monitoring, and meeting practices with the external partner. These costs can have a significant effect on decisions on whether to outsource $R \& D$ work or retain it in-house (Eng \& Wong, 2006; Rindfleisch \& Heide, 1997). The efficiency of governance can be measured on the basis of the efforts required of R\&D managers to manage, control, and steer projects. In this context, successfully adhering to schedules is obviously important, because extending a planned project time also increases the project governance cost. Research has shown that there are several key factors that affect project governance costs. First, previous experience and knowledge accumulated in earlier similar projects are important because experienced teams do not need as much steering and control as teams that are still acquiring competences in the relevant technology. Second, the R\&D team's ability to adapt to the established processes of the lead company is also important, because having that ability reduces the need for project monitoring and meetings, and because an R\&D supplier must adapt to its customer's internal processes and tools (Gulati \& Sytch, 2007; Rindfleisch \& Heide, 1997). A willingness and ability to adapt also supports interaction and creates entrance barriers for competing firms (Brennan \& Turnbull, 1999; Walter, 2003). Third, the cost of negotiating and drafting contracts is an important factor affecting project governance costs, because long-term relationships with trusted partners typically have less need of written agreements than relationships with new partners would. These are important reasons for organizational decisions affecting make-orbuy decisions in dynamic high-technology environments (Bäck \& Kohtamäki, 2015).

\section{Competence}

The competence conception is based on the view that competitive advantage flows from processes that enable value creation from resources and competences (Eisenhardt \& Schoonhoven, 1996). This value creation has a significant strategic meaning in $R \& D$, where joint learning and the development of technological capabilities and skills facilitate the creation of valuable knowledge in internal $R \& D$ and in any collaboration with external suppliers. Having access to the best possible skills and resources to perform each project or task is most important in managerial and organizational decisions, because technological capabilities are usually regarded as primary drivers of R\&D outcomes (Verona, 1999; Wagner \& Hoegl, 2006). The competences and capabilities of prospective partners are usually the key factors in de- 


\section{A Managerial Decision Tool for R\&D Outsourcing and Partner Selection}

\section{Iivari Kunttu}

cisions on whether to outsource $R \& D$ and in any subsequent partner selection process. Other factors in the decision might be the networking performance and networking capabilities of the supplier, because the resources provided by the R\&D supplier network can boost the lead firm's competitiveness (Gulati, 1998; Ritter \& Gemünden, 2003). In the interactions between the customer firm and its supplier network, joint learning is particularly important because it involves the exchange of tacit, experience-based knowledge that is difficult to transfer (Bäck \& Kohtamäki, 2016; Selnes \& Sallis, 2003) and because this kind of joint learning has a positive effect on a firm's innovative performance (Duysters \& Lokshin, 2011; Lin et al., 2012).

\section{Tool Development}

Bäck and Kohtamäki (2015) present example cases of collaborative supplier-customer relationships that were initiated largely on the basis of identity-based decision making, but which over the years of collaboration developed and grew into a form in which they were examined and analyzed in terms of identity, dependence, competence, and efficiency. The primary motivation for developing the R\&D outsourcing tool presented in this article is a key conclusion of the work of Bäck and Kohtamäki (2015), which stated that managers' personal views and organizational traditions tend to dominate $R \& D$ outsourcing decisions, or alternatively the decisions are made based on a single criterion such as governance cost or competence instead of a broader range of criteria. This conclusion supports the use of objective analysis methods based on rational reasoning in organizational decision making that could challenge accepted practices and conventions.

To develop this tool, the author utilized the interview data obtained in a multiple-case study that examined six key R\&D supplier relationships of a leading multinational corporation operating in the area of electrical and electronic devices and systems (Bäck \& Kohtamäki, 2015). The empirical data collection for the research involved meetings and discussions with senior corporate executives responsible for product development, product management, and research to collect general information on the corporation's R\&D activities and supplier involvement strategy. To identify the key factors that affect the outsourcing decisions in the R\&D organizations, data on outsourcing decision making were collected in interviews with $R \& D$ managers who were each responsible for one of the six collaborative relationships with $R \& D$ suppliers. Based on these key factors, which were all related to one of the four concep- tions presented earlier in this article, a set of questions concerning the $\mathrm{R} \& \mathrm{D}$ project outsourcing was formulated. These key questions were then reviewed and analyzed with the group of $R \& D$ managers participating in the interviews.

The R\&D outsourcing decision tool supports make-orbuy decisions in the R\&D area. The purpose of the tool is to analyze outsourcing decisions relating to an $R \& D$ project or task by using a template comprising two phases as presented in Figure 1. The template presented in Table 1 requires $R \& D$ managers to respond to each question related to each conception using a 5-point scale anchored with strongly agree (1) and strongly disagree (5), and to record their reasons for the decision in a description field. In Phase 1, the effect of an outsourcing decision is analyzed based on questions concerning strategy and dependency. Questions related to strategy help managers to consider how much the potential outsourcing of the selected task aligns with their firm's R\&D strategy. Empirical observations in R\&D organizations (Bäck \& Kohtamäki, 2015). suggest that, in many cases, managers must first define the strategic goals of their organization before they can be made available to guide strategy-based decisions. At the end of Phase 1, the tool calculates a summary score for both strategy and dependency viewpoints. These scores provide an indication of whether outsourcing would be an appropriate course of action. Phase 2 involves assessing the expected efficiency and competence of the external supplier candidates against those of the internal $R \& D$ function. Again, the tool calculates a summary score for both efficiency and competence, but in this case, the scores are calculated for all supplier candidates and for an internal $R \& D$ operation separately. Thus, the user can compare the scores of internal $R \& D$ and supplier candidates and use that information as a basis for the outsourcing or insourcing decision.

\section{Conclusion}

Managers in high-technology industries decide whether to outsource $R \& D$ work based on their previous experience or interpretations of the environment. These interpretations can be influenced by personal, subjective views or by tangible factors. Instead of concentrating only on previous experience or personal opinions, or solely on a prospective partner's efficiency or competence, it would be beneficial for managers responsible for $R \& D$ supplier relations to adopt a range of viewpoints to support their decisions. This study presents four theoretically and empirically grounded conceptions - effectiveness, efficiency, competence, and 


\section{A Managerial Decision Tool for R\&D Outsourcing and Partner Selection}

\section{Iivari Kunttu}

dependence - available for use when evaluating the benefits of $R \& D$ collaboration with external suppliers. Previous research identified several factors related to those conceptions that affect how firms select their R\&D suppliers and how the decisions on outsourcing $R \& D$ tasks are being made. Those factors provide the foundation of the practical decision template presented in this study.

The main contribution of this study is to present a tool capable of facilitating the decision-making process related to R\&D outsourcing and partner selection. It provides a practical but theoretically grounded way to rapidly evaluate and compare internal $R \& D$ capabilities with those available externally. When adopting and using the tool, customer R\&D organizations may also need to define and elaborate their R\&D strategy by considering their core capabilities and defining general guidelines for outsourcing activities. These activities in turn facilitate the change from identity-based decision making to decision making based on a broadly accepted organizational strategy. Given that the tool has primarily been developed to assist decisions concerning the potential outsourcing of R\&D tasks, it is not a primary choice for decisions on innovation or research collaboration aiming for joint learning and knowledge creation. The development of a tool for facilitating partner selection in those cases is a natural subject for further research in this field.

\section{Acknowledgments}

This article emerges from the research project FIMECC S4Fleet. The financial support of the Finnish Funding Agency for Technology and Innovation is gratefully acknowledged.

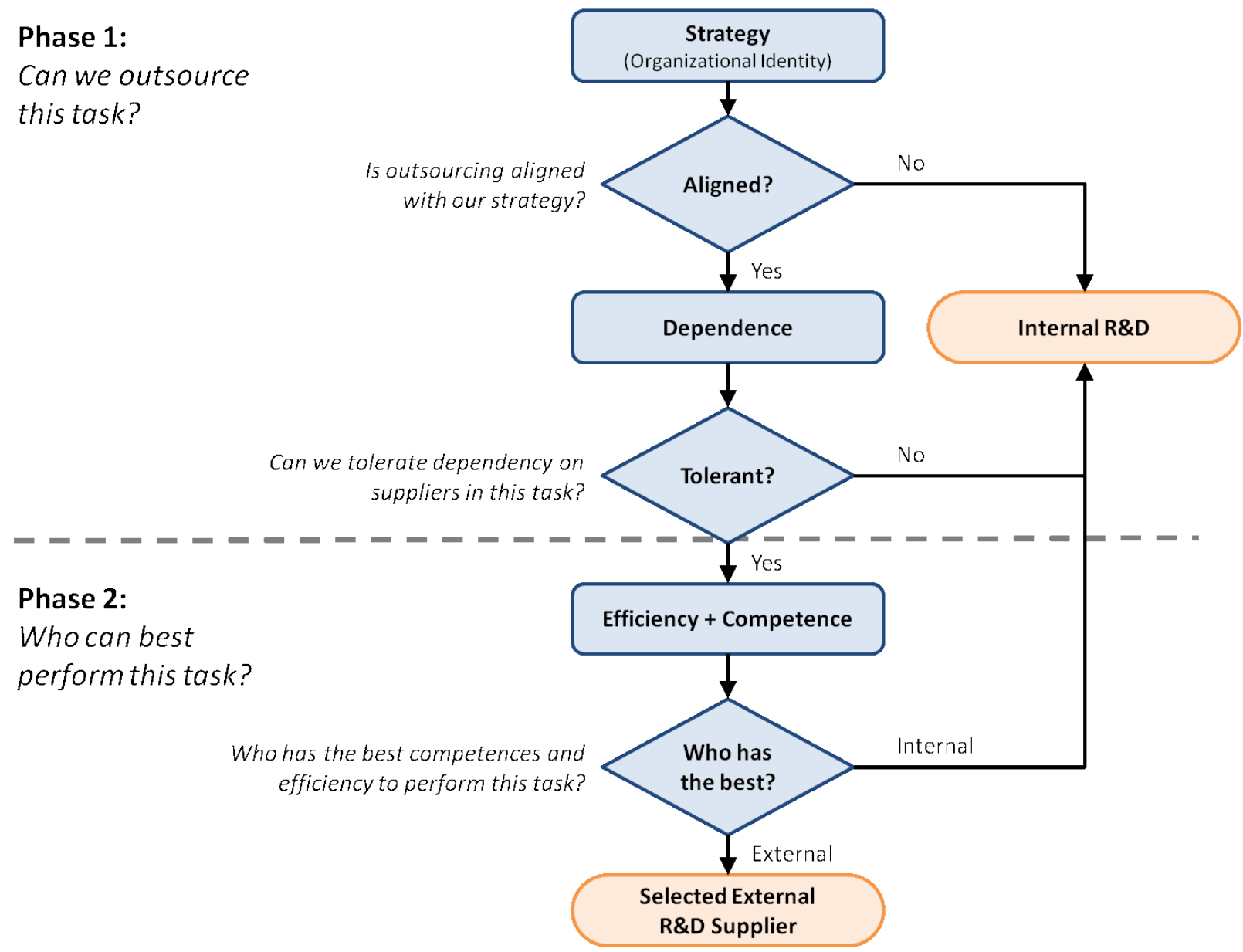

Figure 1. Outline of the R\&D outsourcing decision tool 


\section{A Managerial Decision Tool for R\&D Outsourcing and Partner Selection Iivari Kunttu}

Table 1. Template of the R\&D outsourcing and partner selection decision tool

\begin{tabular}{|c|c|c|c|c|c|}
\hline Phase 1 & Question / Statement & $\begin{array}{l}\text { Evaluation }(1 \ldots 5) \\
\text { (1=strongly agree, } \\
5=\text { strongly disagree) }\end{array}$ & \multicolumn{3}{|c|}{ Comments/Reasons } \\
\hline \multirow{4}{*}{$\begin{array}{l}\text { Identity and } \\
\text { Strategy }\end{array}$} & The task belongs to our core business / core competence area. & & & & \\
\hline & Carrying out this task by ourselves is in line with our R\&D strategy. & & & & \\
\hline & $\begin{array}{l}\text { Carrying out this task by ourselves is the best decision from the viewpoint } \\
\text { of our organization's operation, competence, and identity. }\end{array}$ & & & & \\
\hline & SUMMARY (Average number) & & \multicolumn{3}{|c|}{$\begin{array}{l}1 \text { suggests outsourcing, } \\
5 \text { suggests insourcing }\end{array}$} \\
\hline \multirow{5}{*}{ Dependence } & $\begin{array}{l}\text { Outsourcing the task will probably lead to strong dependence on the } \\
\text { selected partner. }\end{array}$ & & & & \\
\hline & It would be particularly difficult to change the partner afterwards. & & & & \\
\hline & It would be particularly difficult to insource the task afterwards. & & & & \\
\hline & $\begin{array}{l}\text { We will not maintain replacement partnerships (second sources) or } \\
\text { internal competences to limit dependence on the selected partner. }\end{array}$ & & & & \\
\hline & SUMMARY (Average number) & & \multicolumn{3}{|c|}{$\begin{array}{l}1 \text { suggests outsourcing, } \\
5 \text { suggests insourcing }\end{array}$} \\
\hline Phase 2 & Question / Statement & $\begin{array}{l}\text { Internal R\&D } \\
\quad(1 \ldots 5)\end{array}$ & $\begin{array}{l}\text { Supplier } 1 \\
\quad(1 \ldots . .5)\end{array}$ & $\begin{array}{l}\text { Supplier } 2 \\
\quad(1 \ldots .5)\end{array}$ & $\begin{array}{l}\text { Supplier } 3 \\
\quad(1 \ldots .5)\end{array}$ \\
\hline \multirow{6}{*}{ Efficiency } & $\begin{array}{l}\text { The total cost of the project/task will probably be reasonable when } \\
\text { compared to common cost level. }\end{array}$ & & & & \\
\hline & $\begin{array}{l}\text { Governance and steering costs of the project/task will probably be small } \\
\text { (i.e., we do not need to commit much of our own time and resources to } \\
\text { project management). }\end{array}$ & & & & \\
\hline & $\begin{array}{l}\text { Collaboration between project/task stakeholders and communication } \\
\text { will probably be easy. }\end{array}$ & & & & \\
\hline & It is expected that time schedules and agreements will be adhered to. & & & & \\
\hline & The need to control the deliverables is minor. & & & & \\
\hline & $\begin{array}{l}\text { SUMMARY (Average number for each column) } \\
\text { (1 suggests low efficiency, } 5 \text { suggests high efficiency) }\end{array}$ & & & & \\
\hline \multirow{5}{*}{$\begin{array}{l}\text { Competences } \\
\text { and Resources }\end{array}$} & $\begin{array}{l}\text { This party has the best possible competence and resources to carry out } \\
\text { the task. }\end{array}$ & & & & \\
\hline & $\begin{array}{l}\text { This party will commit to developing its competences and capabilities } \\
\text { relating to this task. }\end{array}$ & & & & \\
\hline & This party has sufficient capacity to carry out the task. & & & & \\
\hline & $\begin{array}{l}\text { Having this party carry out the task provides opportunities for new } \\
\text { learning and to deliver innovations. }\end{array}$ & & & & \\
\hline & $\begin{array}{l}\text { SUMMARY (Average number for each column) } \\
\text { (1 suggests low competences, } 5 \text { suggests high competences) }\end{array}$ & & & & \\
\hline
\end{tabular}




\section{A Managerial Decision Tool for R\&D Outsourcing and Partner Selection}

\section{Iivari Kunttu}

\section{About the Author}

Iivari Kunttu is an Assistant Professor in Department of Management of the University of Vaasa, Finland. He holds a PhD degree in Information Technology from the Tampere University of Technology (TUT) and has held several R\&D manager and R\&D process development specialist positions in the Nokia Corporation and project manager positions in TUT. His current research interests include $R \& D$ management, $\mathrm{R} \& \mathrm{D}$ supplier involvement, service business development, and innovation management.

\section{References}

Brennan, R., \& Turnbull, P. W. 1999. Adaptive Behavior in Buyer-Supplier Relationships. Industrial Marketing Management, 28(5): 481-495. http://doi.org/10.1016/S0019-8501(99)00057-7

Brown, A. D., \& Starkey, K. 2000. Organizational Identity and Learning: A Psychodynamic Perspective. The Academy of Management Review, 25(1): 102-120. http://doi.org/10.2307/259265

Bäck, I., \& Kohtamäki, M. 2015. Boundaries of R\&D Collaboration. Technovation, 45-46: 15-28. http://doi.org/10.1016/j.technovation.2015.07.002

Bäck, I., \& Kohtamäki, M. 2016. Joint Learning in Innovative R\&D Collaboration. Industry and Innovation, 23(1): 62-86. http://doi.org/10.1080/13662716.2015.1123613

Duysters, G., \& Lokshin, B. 2011. Determinants of Alliance Portfolio Complexity and Its Effect on Innovative Performance of Companies. Journal of Product Innovation Management, 28(4): 570-585.

http://doi.org/10.1111/j.1540-5885.2011.00824.x

Dyer, J. H. 1996. Does Governance Matter? Keiretsu Alliances and Asset Specificity as Sources of Japanese Competitive Advantage. Organization Science, 7(6): 649-666. http://doi.org/10.1287/orsc.7.6.649

Eisenhardt, K. M., \& Schoonhoven, C. B. 1996. Resource-Based View of Strategic Alliance Formation: Strategic and Social Effects in Entrepreneurial Firms. Organization Science, 7(2): 136-151. http://dx.doi.org/10.1287/orsc.7.2.136

Eng, T.-Y., \& Wong, V. 2006. Governance Mechanisms and Relationship Productivity in Vertical Coordination for New Product Development. Technovation, 26(7): 761-769.

http://doi.org/10.1016/j.technovation.2004.10.015

Geringer, M. 1991. Strategic Determinants of Partner Selection Criteria in International Joint Ventures. Journal of International Business Studies, 22(1): 41-62.

http://doi.org/10.1057/palgrave.jibs.8490291
Gulati, R. 1998. Alliances and Networks. Strategic Management Journal, 19(4): 293-317.

http://doi.org/10.1002/(SICI) 1097-0266(199804)19:4<293::AID-

SMJ982>3.0.CO;2-M

Gulati, R., \& Sytch, M. 2007. Dependence Asymmetry and Joint Dependence in Interorganizational Relationships: Effects of Embeddedness on a Manufacturer's Performance in Procurement Relationships. Administrative Science Quarterly, 52(1): 32-69. http://dx.doi.org/10.2189/asqu.52.1.32

Heide, J. B., \& Weiss, A. M. 1995. Vendor Consideration and Switching Behavior for Buyers in High-Technology Markets. Journal of Marketing, 59(3): 30-43. http://doi.org/10.2307/1252117

Johnsen, T. E. 2009. Supplier Involvement in New Product Development and Innovation: Taking Stock and Looking to the Future. Journal of Purchasing and Supply Management, 15(3): 187-197.

http://doi.org/10.1016/j.pursup.2009.03.008

Lambe, C. J., Spekman, R. E., \& Hunt, S. D. 2002. Alliance Competence, Resources, and Alliance Success: Conceptualization, Measurement, and Initial Test. Journal of the Academy of Marketing Science, 30(2): 141-158.

Laursen, K., \& Salter, A. 2006. Open for Innovation: The Role of Openness in Explaining Innovation Performance among U.K. Manufacturing Firms. Strategic Management Journal, 27(2): 131-150.

http://doi.org/10.1002/smj.507

Lin, C., Wu, Y.-J., Chang, C., Wang, W., \& Lee, C.-Y. 2012. The Alliance Innovation Performance of R\&D Alliances-The Absorptive Capacity Perspective. Technovation, 32(5): 282-292.

http://doi.org/10.1016/j.technovation.2012.01.004

Mayer, K. J., \& Nickerson, J. A. 2005. Antecedents and Performance Implications of Contracting for Knowledge Workers: Evidence from Information Technology Services. Organization Science, 16(3): 225-242.

http://doi.org/10.1287/orsc.1050.0125

Paananen, M. 2012. I'll Find it Where I Can: Exploring the Role of Resource and Financial Constraints in Search Behaviour among Innovators. Industry and Innovation, 19(1): 63-84. http://dx.doi.org/10.1080/13662716.2012.649059

Quinn, J. B. 2000. Outsourcing Innovation: The New Engine of Growth. MIT Sloan Management Review, 41(4): 13-28.

Rindfleisch, A., \& Heide, J. B. 1997. Transaction Cost Analysis: Past, Present, and Future Applications. Journal of Marketing, 61(4): 30-54.

http://doi.org/10.2307/1252085

Ritter, T., \& Gemünden, H. G. 2003. Network Competence. Journal of Business Research, 56(9): 745-755. http://doi.org/10.1016/S0148-2963(01)00259-4

Santos, F. M., \& Eisenhardt, K. M. 2005. Organizational Boundaries and Theories of Organization. Organization Science, 16(5): 491-508.

http://doi.org/10.1287/orsc.1050.0152

Selnes, F., \& Sallis, J. 2003. Relationship Promoting Learning. Journal of Marketing, 67(3): 80-95.

http://dx.doi.org/10.1509/jmkg.67.3.80.18656 


\section{A Managerial Decision Tool for R\&D Outsourcing and Partner Selection}

\section{Iivari Kunttu}

Teece, D. J., Pisano, G., \& Shuen, A. 1997. Dynamic Capabilities and Strategic Management. Strategic Management Journal, 18(7): 509-533.

http://www.jstor.org/stable/3088148

Verona, G. 1999. A Resource-Based View of Product Development. Academy of Management Review, 24(1): 132-142. http://doi.org/10.5465/AMR.1999.1580445

Wagner, S. M., \& Hoegl, M. 2006. Involving Suppliers in Product Development: Insights from R\&D Directors and Project Managers. Industrial Marketing Management, 35(8): 936-943. http://doi.org/10.1016/j.indmarman.2005.10.009

Walter, A. 2003. Relationship-Specific Factors Influencing Supplier Involvement in Customer New Product Development. Journal of Business Research, 56(9): 721-733.

http://doi.org/10.1016/S0148-2963(01)00257-0

Weick, K. E., Sutcliffe, K. M., \& Obstfeld, D. 2005. Organizing and the Process of Sensemaking. Organization Science, 16(4): 409-421. http://doi.org/10.1287/orsc.1050.0133

Wittmann, C. M., Hunt, S. D., \& Arnett, D. B. 2009. Explaining Alliance Success: Competences, Resources, Relational Factors, and Resource-Advantage Theory. Industrial Marketing Management, 38(7): 743-756.

http://doi.org/10.1016/j.indmarman.2008.02.007

Citation: Kunttu, I. 2017. A Managerial Decision Tool for R\&D Outsourcing and Partner Selection in High-

\section{(cc) BY}

Technology Industries. Technology Innovation

Management Review, 7(3) 25-32.

http://timreview.ca/article/1062

Keywords: research and development, supplier involvement, outsourcing, partner selection, decision tool 